\title{
Ghrelin regulates cell cycle-related gene expression in cultured hippocampal neural stem cells
}

\author{
Hyunju Chung ${ }^{1}$ and Seungjoon Park ${ }^{2}$ \\ 'Department of Core Research Laboratory, Clinical Research Institute, Kyung Hee University Hospital at \\ Gangdong, Seoul, Korea \\ 2Department of Pharmacology and Medical Research Center for Bioreaction to ROS and Biomedical \\ Science Institute, School of Medicine, Kyung Hee University, Seoul, Korea
}

\author{
Correspondence \\ should be addressed \\ to S Park \\ Email \\ sjpark@khu.ac.kr
}

\begin{abstract}
We have previously demonstrated that ghrelin stimulates the cellular proliferation of cultured adult rat hippocampal neural stem cells (NSCs). However, little is known about the molecular mechanisms by which ghrelin regulates cell cycle progression. The purpose of this study was to investigate the potential effects of ghrelin on cell cycle regulatory molecules in cultured hippocampal NSCs. Ghrelin treatment increased proliferation assessed by CCK-8 proliferation assay. The expression levels of proliferating cell nuclear antigen and cell division control 2, well-known cell-proliferating markers, were also increased by ghrelin. Fluorescence-activated cell sorting analysis revealed that ghrelin promoted progression of cell cycle from $G_{0} / G_{1}$ to $S$ phase, whereas this progression was attenuated by the pretreatment with specific inhibitors of MEK/extracellular signalregulated kinase 1/2, phosphoinositide 3-kinase/Akt, mammalian target of rapamycin, and janus kinase 2/signal transducer and activator of transcription 3. Ghrelin-induced proliferative effect was associated with increased expression of E2F1 transcription factor in the nucleus, as determined by Western blotting and immunofluorescence. We also found that ghrelin caused an increase in protein levels of positive regulators of cell cycle, such as cyclin A and cyclin-dependent kinase (CDK) 2. Moreover, p27KIP1 and $\mathrm{p} 57^{\mathrm{KIP} 2}$ protein levels were reduced when cell were exposed to ghrelin, suggesting downregulation of CDK inhibitors may contribute to proliferative effect of ghrelin. Our data suggest that ghrelin targets both cell cycle positive and negative regulators to stimulate proliferation of cultured hippocampal NSCs.
\end{abstract}

\author{
Key Words \\ - ghrelin \\ - hippocampus \\ - progenitor \\ - proliferation \\ - cell cycle
}

Journal of Endocrinology (2016) 230, 239-250

\section{Introduction}

Ghrelin is a unique 28-amino acid peptide hormone mainly produced in the stomach. The peptide is known to act through the activation of the growth hormone (GH) secretagogue receptor 1a (Kojima et al. 1999). Earlier studies revealed that ghrelin exerts a stimulatory influence on GH release primarily at the levels of anterior pituitary and hypothalamus and enhances food intake to regulate body weight and energy homeostasis (Date et al. 2000). Ghrelin also has wide variety of physiological actions throughout the body, including effects on exocrine and endocrine pancreatic functions, carbohydrate metabolism, the cardiovascular system, gastric secretion, stomach motility

Published by Bioscientifica Ltd 
and sleep (Van der Lely et al. 2004, Ghigo et al. 2005, Kojima \& Kangawa 2005). In the central nervous system (CNS), ghrelin shows various nonendocrine effects to control different brain functions, such as enhancement of learning and memory (Diano et al. 2006), attenuation of anxiety and depression (Carlini et al. 2004, Lutter et al. 2008), modulation of reward and motivation (Naleid et al. 2005, Abizaid et al. 2006, Jiang et al. 2006), and protection of neuronal cells (Chung et al. 2007, 2008, Miao et al. 2007, Jiang et al. 2008, Hwang et al. 2009, Moon et al. 2009a, Lee et al. 2010a,b).

Neurogenesis is known to persist throughout adulthood in several mammalian species in the hippocampus, especially the subgranular zone of the dentate gyrus (DG) and in the subventricular zone of the lateral ventricle (Ming \& Song 2005, Zhao et al. 2008). Hippocampus plays an important role in the process of learning, memory and emotional responses (Zhao et al. 2008); hence, a lot of attention has been paid on hippocampal neurogenesis. Exact understanding of the mechanisms involved in the adult hippocampal neurogenesis may augment the development of new therapy using stem-cell-based strategies against neurodegenerative diseases. We have previously reported that ghrelin regulates adult hippocampal neurogenesis in vivo and in vitro. Specifically, ghrelin administration enhances hippocampal neurogenesis in adult mice (Moon et al. 2009b). Our studies using ghrelin-knockout mice demonstrated that deletion of ghrelin resulted in lower numbers of progenitor cells in the DG, whereas ghrelin treatment restored progenitor cell numbers to those of wild-type controls (Li et al. 2013). Furthermore, we also reported that ghrelin induces cellular proliferation of cultured adult rat hippocampal neural stem cells (NSCs) via the activation of extracellular signal-regulated protein kinases 1 and 2 (ERK1/2), phosphoinositide 3-kinase (PI3K)/Akt/glycogen synthase kinase (GSK)-3 $\beta$, PI3K/Akt/mammalian target of rapamycin (mTOR)/p70s6K and janus kinase (JAK) 2/signal transducer, and activator of transcription (STAT) 3 signaling pathways (Chung et al. 2013). Collectively, these data suggest that ghrelin acts as a neurogenic agent. However, the precise mechanism of this stimulatory effect of ghrelin on hippocampal NSCs proliferation has not been fully understood.

Several cell cycle molecules and signaling pathways have been implicated in the regulation of adult hippocampal neurogenesis (Patricio et al. 2013). The progression of cell cycle is regulated by the activities of two important cell cycle regulators, cyclins and cyclin-dependent kinases (CDKs) (Beukelaers et al. 2012).
During the $G_{1}$ phase, cyclin D-CDK4/6 complexes are activated. Cyclin $\mathrm{E}$ and $\mathrm{A}$, together with their catalytic enzyme, CDK2, are necessary for the advancement of the cell cycle from the $G_{1}$ into $S$ phase and progression through $\mathrm{S}$ phase, respectively. Cyclin B-CDK1 complexes contribute to $\mathrm{M}$ phase entry. The transcription factor E2F1 is involved in the regulation of cell cycle regulation (Yoshikawa 2000). Additionally, the activity of cyclinCDK complex can be regulated by the inhibitory interaction with CDK inhibitors (CKIs), such as p21CIP1, p27KIP1 and p57KIP2 (Vidal \& Koff 2000). Therefore, the balance between the levels of promitogenic cyclins and antimitogenic CKIs is thought to be important for the progression into $S$ phase. Mitogenic signals, such as insulin-like growth factor-1 (IGF-1) and basic fibroblast growth factor (bFGF), are known to stimulate proliferation of cortical precursors through upregulation of cyclins and downregulation of CKIs (Li \& CiccoBloom 2004, Mairet-Coello et al. 2009). In contrast, pituitary adenylate cyclase-activating polypeptide exerts antimitogenic effect via augmenting expression of p57KIP2 (Carey et al. 2002). Moreover, it has been reported that ghrelin promotes cell cycle progression in intestinal epithelial cells (Waseem et al. 2014) and augments the expression of positive regulators of cell cycle progression in murine T-cells (Lee et al. 2014). Based on these findings, we hypothesized that the proliferative actions of ghrelin on hippocampal NSCs may be related to control of cell cycle molecules. At present, no data are available on the effects of ghrelin on cell cycle regulators in hippocampal NSCs. Therefore, in this study, we performed a series of experiments in order to pursue further the biological effects of ghrelin in the CNS and determine the neurogenic mechanism of action of ghrelin in adult rat hippocampal NSCs. We found that ghrelin-mediated proliferation was associated with the induction of nuclear E2F1 and regulation of other cell cycle-related genes.

\section{Materials and methods}

\section{Materials}

Rat ghrelin was obtained from Peptides International (Louisville, KT, USA). NSC expansion media, Dulbecco's modified Eagle's medium (DMEM)/F12 and B27 supplement were obtained from Gibco/Invitrogen. B-27 is an optimized serum substitute developed for low-density plating and long-term viability and growth of CNS neurons (Brewer et al. 1993). PD98059, U0126,

Published by Bioscientifica Ltd 
LY294002, rapamycin and cucurbitacin I were obtained from Tocris (Ellisville, MO, USA) and Akt inhibitor VIII was procured from Santa Cruz Biotechnology. All tissue culture reagents were obtained from Gibco/Invitrogen, and all other reagents were purchased from Sigma, unless otherwise indicated.

\section{Adult rat hippocampal NSC cultures and treatments}

Adult rat hippocampal NSCs were obtained from Chemicon (Catalog No. SCR022). These cells are ready-to-use primary NSCs isolated from the hippocampus of adult Fisher 344 rats. They were grown in an NSC expansion medium containing DMEM/F12 medium with L-glutamine, B27 supplement, $1 \times$ solution of penicillin, streptomycin and fungizone, and bFGF $(20 \mathrm{ng} / \mathrm{mL})$. Tissue culture plastic- or glass wares that were used to culture hippocampal NSCs were coated with poly-L-ornithine $(10 \mu \mathrm{g} / \mathrm{mL})$ and laminin $(5 \mu \mathrm{g} / \mathrm{mL})$. The hippocampal NSCs were maintained at $37^{\circ} \mathrm{C}$ in a $5 \% \mathrm{CO}_{2}$ humidified incubator and passaged once every 5-6 days. To determine whether ghrelin stimulates the proliferation of hippocampal NSCs, cells were treated with ghrelin $(100 \mathrm{nM})$ for 24,48 , and $72 \mathrm{~h}$. This dose of ghrelin $(100 \mathrm{nM})$ was selected on the basis of our previous report showing that it increased the proliferation of hippocampal NSCs and it was the lowest dose with the maximum response (Chung et al. 2013). Experiments were also performed by incubating the cells with the following pharmacological inhibitors: $20 \mu \mathrm{M}$ PD98059 for $0.5 \mathrm{~h}, 10 \mu \mathrm{M}$ U0126 for $0.5 \mathrm{~h}, 20 \mu \mathrm{M}$ LY294002 for 1h, 100 nM Akt inhibitor VIII for $1 \mathrm{~h}, 200 \mathrm{nM}$ rapamycin for $1 \mathrm{~h}$ or $1 \mathrm{nM}$ cucurbitacin I for $0.5 \mathrm{~h}$. All experiments were performed three times in duplicate.

\section{Evaluation of cell proliferation using CCK-8 proliferation assay}

Experiments for cell proliferation were performed in 24well plates. Cells were seeded at a density of $1 \times 10^{5}$ cells $/ \mathrm{mL}$ of neuronal expansion media containing bFGF. After $24 \mathrm{~h}$, the media were replaced with fresh media with ghrelin $(100 \mathrm{nM})$ or a vehicle and incubated for 24,48 and $72 \mathrm{~h}$. The cell proliferation was determined using the CCK-8 proliferation assay (Enzo Life Sciences, Lausen, Switzerland) according to the manufacturer's instructions. In brief, $20 \mu \mathrm{L}$ CCK-8 solution were added into each well (containing $200 \mu \mathrm{L}$ medium), and further cultured for $2 \mathrm{~h}$ at $37^{\circ} \mathrm{C}$. The absorbance of each group at $450 \mathrm{~nm}$ was detected $(n=3)$ using an absorbance microplate reader
(Molecular Devices, LLC, Sunnyvale, CA, USA) and it was directly proportional to the number of living cells.

\section{Fluorescence-activated cell sorting (FACS) analysis}

Cell cycle distribution was examined by FACS analysis. $1 \times 10^{6}$ cells were collected and fixed with $3.7 \%$ paraformaldehyde. After fixation, the propidium iodide $(50 \mu \mathrm{g} / \mathrm{mL})$-staining solution with RNase A (BD Biosciences, San Jose, CA, USA) was added. After 30-min incubation, the cells were filtered on a nylon mesh filter. Stained samples were analyzed by flow cytometric analysis using FACSCalibur (BD Biosciences, San Jose, CA, USA).

\section{Real-time RT-PCR}

Total RNA from hippocampal NSCs was extracted using the Qiagen RNeasy Mini Kit (Qiagen) according to the manufacturer's instructions and was reverse transcribed using the Superscript II reverse transcriptase (Life Technologies) at $42^{\circ} \mathrm{C}$ with random hexamer priming. An RNA control tube containing all reverse transcription reagents except reverse transcriptase was included as a negative control to monitor genomic DNA contamination. Real-time RT-PCR was used to determine mRNA levels of proliferating cell nuclear antigen (PCNA) and cell division control (CDC) 2 in hippocampal NSCs using primers specific for PCNA and CDC2 (The Rat Cell Cycle RT2 ${ }^{2}$ Profiler PCR Array, Qiagen), and $\beta$-actin (sense: 5'-ATG GGT CAG AAG GAC TCC TAC G-3' and antisense: 5'-AGT GGT ACG ACC AGA GGC ATA C-3'). Reactions were performed using the StepOnePlus Real-Time PCR System (Applied Biosystems).

\section{Western blotting}

Cells were lysed in a buffer containing $20 \mathrm{mM}$ Tris- $\mathrm{HCl}$ (pH 7.4), $1 \mathrm{mM}$ EDTA, $140 \mathrm{mM} \mathrm{NaCl}, 1 \%$ (w/v) Nonidet P-40, $1 \mathrm{mM} \quad \mathrm{Na}_{3} \mathrm{VO}_{4}, 1 \mathrm{mM}$ phenylmethylsulfonyl fluoride, $50 \mathrm{mM} \mathrm{NaF}$ and $10 \mu \mathrm{g} / \mathrm{mL}$ aprotinin. Cell lysates were separated by $12 \%$ SDS-PAGE and electrotransferred onto polyvinylidene difluoride membranes (Bio-Rad). For the detection of E2F1, cells were fractionated into nuclear and cytoplasmic contents using the Nuclear/Cytoplasmic Extraction Kit (Pierce Biotechnology) according to the manufacturer's instructions. The membranes were soaked in a blocking buffer (1× Tris-buffered saline (TBS), 1\% bovine serum albumin (BSA) and 1\% nonfat dry milk) for $1 \mathrm{~h}$ and incubated overnight at $4^{\circ} \mathrm{C}$ with the primary

Published by Bioscientifica Ltd. 
A
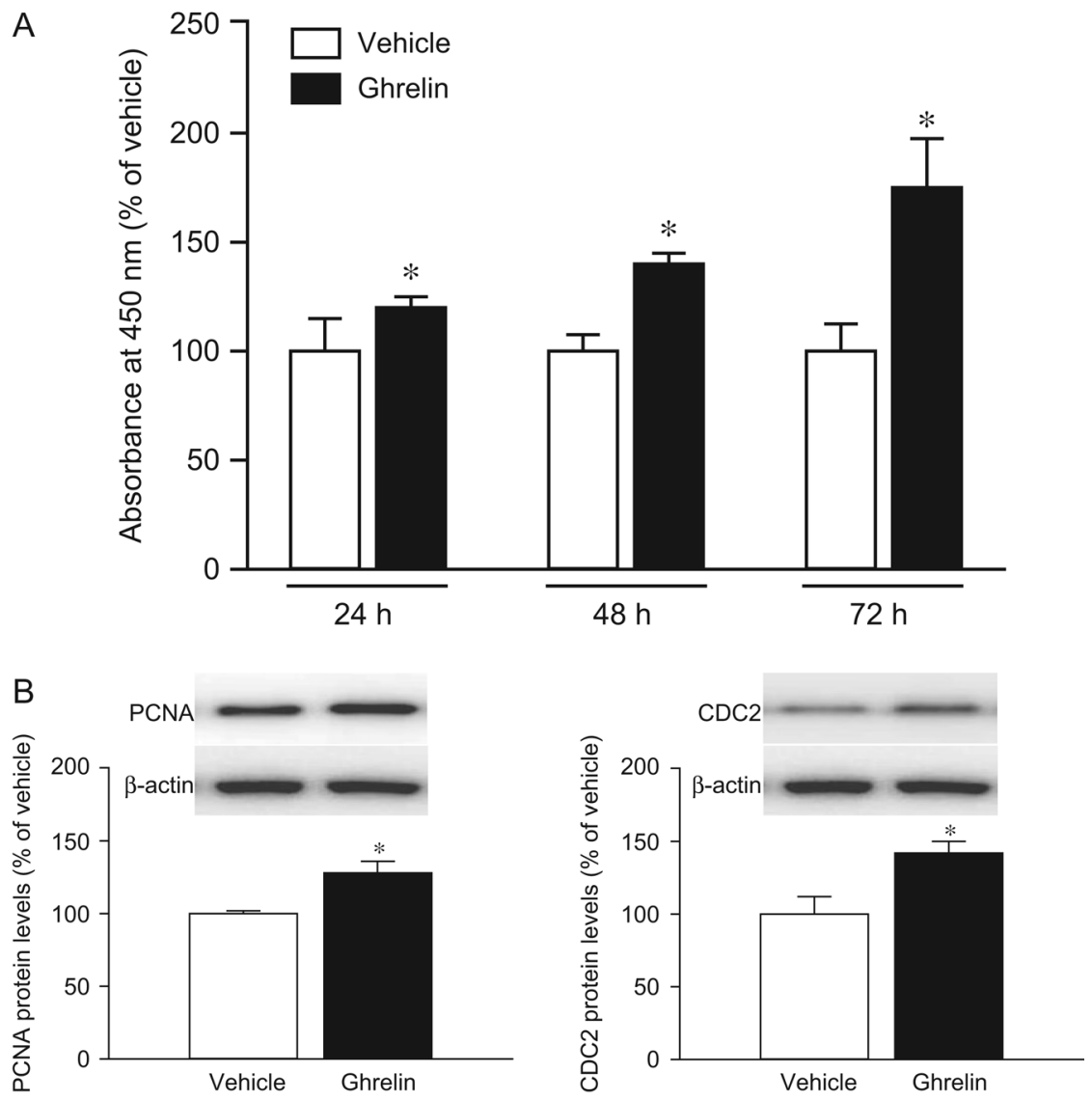

Figure 1

Ghrelin stimulates proliferation of adult rat hippocampal NSCs. (A) Cells were treated with ghrelin (100 nM) for 24,48 and $72 \mathrm{~h}$, and the cell proliferation was assayed using the CCK-8 proliferation assay. (B) Cells were treated with ghrelin $(100 \mathrm{nM})$ for $24 \mathrm{~h}$. Protein lysates were prepared and assayed by Western blotting using specific anti-PCNA and anti-CDC2 antibodies. The band intensities of PCNA and CDC2 were normalized to the band intensity of $\beta$-actin. (C) Time course of ghrelin-induced effects on PCNA and CDC2 mRNA levels. Cells were treated with ghrelin $(100 \mathrm{nM})$ for $4,8,12$ and $24 \mathrm{~h}$. Real-time RT-PCR was performed to measure mRNA levels of PCNA and CDC2 and adjusted by $\beta$-actin. The data are expressed as percentage of vehicle and are shown as the mean \pm s.E.M. of three different experiments (each experiment was performed in duplicate). ${ }^{*} P<0.05$ vs vehicle-treated control.

antibodies against PCNA, CDC2, Laminin A, GAPDH (Cell Signaling; 1:1000), and CDK2, cyclin A, p27KIP1 and p57KIP2, E2F1 (Santa Cruz Biotechnology; 1:1000). Blots were developed using a peroxidase-conjugated antirabbit IgG and a chemiluminescent detection system (Santa Cruz Biotechnology). The bands were visualized using a ChemiDoc XRS system (Bio-Rad) and quantified using Quantity One imaging software (Bio-Rad).

\section{Immunocytochemistry}

Adult rat hippocampal NSCs were fixed in $4 \%$ paraformaldehyde for $20 \mathrm{~min}$ at room temperature. Cells were washed twice with phosphate-buffered saline (PBS) and permeabilized with PBS containing 0.4\% Triton X-100 for $20 \mathrm{~min}$, followed by blocking with TBS containing $0.02 \%$ Tween 20 and $10 \%$ normal goat serum for $1 \mathrm{~h}$ at room temperature. Primary antibody incubations were performed at $4^{\circ} \mathrm{C}$ overnight in TBS containing $0.02 \%$ Tween 20 and 3\% BSA. Cells were incubated in a blocking solution $(0.3 \%$ Triton X-100, 1\% BSA and 3\% normal goat serum in PBS) for $2 \mathrm{~h}$. After overnight incubation with primary antibody against E2F1 (1:400; Santa Cruz Biotechnology) at $4^{\circ} \mathrm{C}$, cells were rinsed with $\mathrm{PBS}$, followed by incubation with a secondary antibody (Alexa Fluor 488 goat antirabbit IgG, 1:400, Invitrogen) for $4 \mathrm{~h}$ at 
A
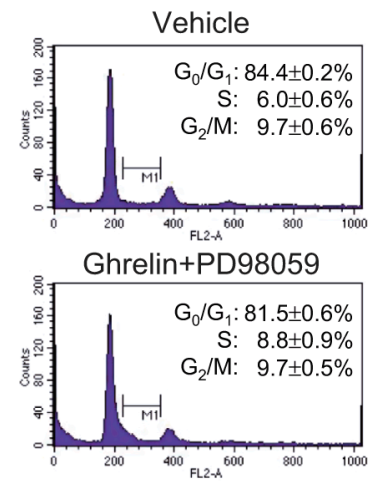

Ghrelin+LY294002

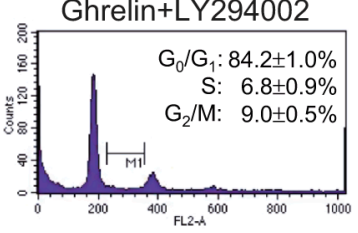

Ghrelin+Rapamycin

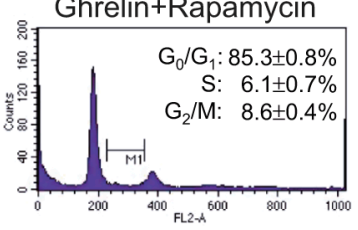

B

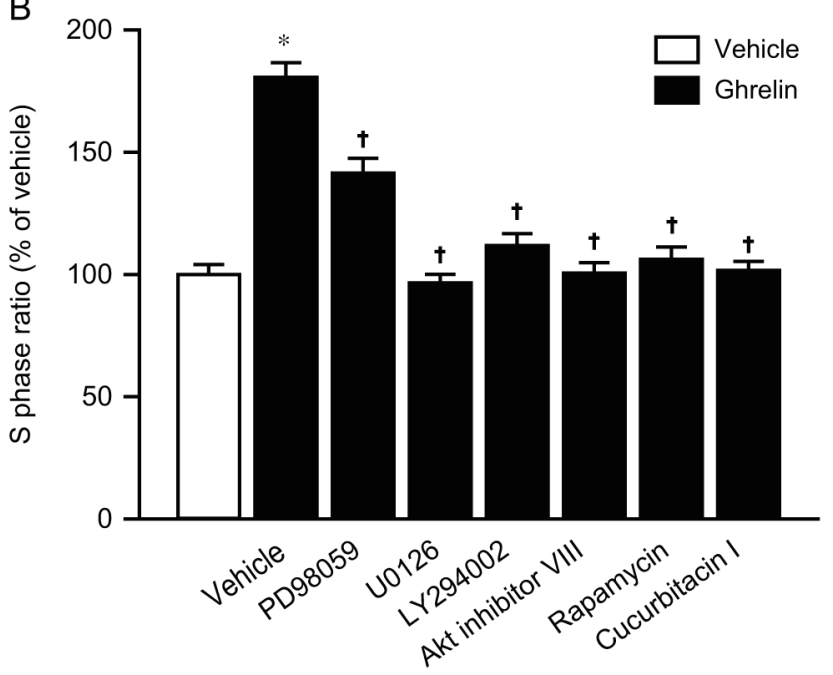

Figure 2

Fluorescence-activated cell sorting (FACS) analysis of cell cycle

distribution. (A) Following 16-h starvation and pretreatment with $20 \mu \mathrm{M}$ PD98059 for $0.5 \mathrm{~h}, 10 \mu \mathrm{M}$ U0126 for $0.5 \mathrm{~h}, 20 \mu \mathrm{M}$ LY294002 for $1 \mathrm{~h}, 100 \mathrm{nM}$ Akt inhibitor VIII for $1 \mathrm{~h}, 200 \mathrm{nM}$ rapamycin for $1 \mathrm{~h}$ or $1 \mathrm{nM}$ cucurbitacin I for $0.5 \mathrm{~h}$, cells were treated with ghrelin $(100 \mathrm{nM})$ for $8 \mathrm{~h}$. The cells were harvested by propidium iodide $(50 \mu \mathrm{g} / \mathrm{mL})$-staining solution and subjected to FACS analysis. Results were expressed as percentage of total cells in $\mathrm{G}_{0} / \mathrm{G}_{1}, \mathrm{~S}$ or $\mathrm{G}_{2} / \mathrm{M}$ phase of the cell cycle. Values represent the mean \pm S.E.M. of three different experiments (each experiment was performed in duplicate). (B) The bar graphs represent the $S$ phase ratio expressed as the percentage of vehicle. ${ }^{*} P<0.05$ vs vehicle-treated cells, ${ }^{t} P<0.05$ vs ghrelin-treated cells.
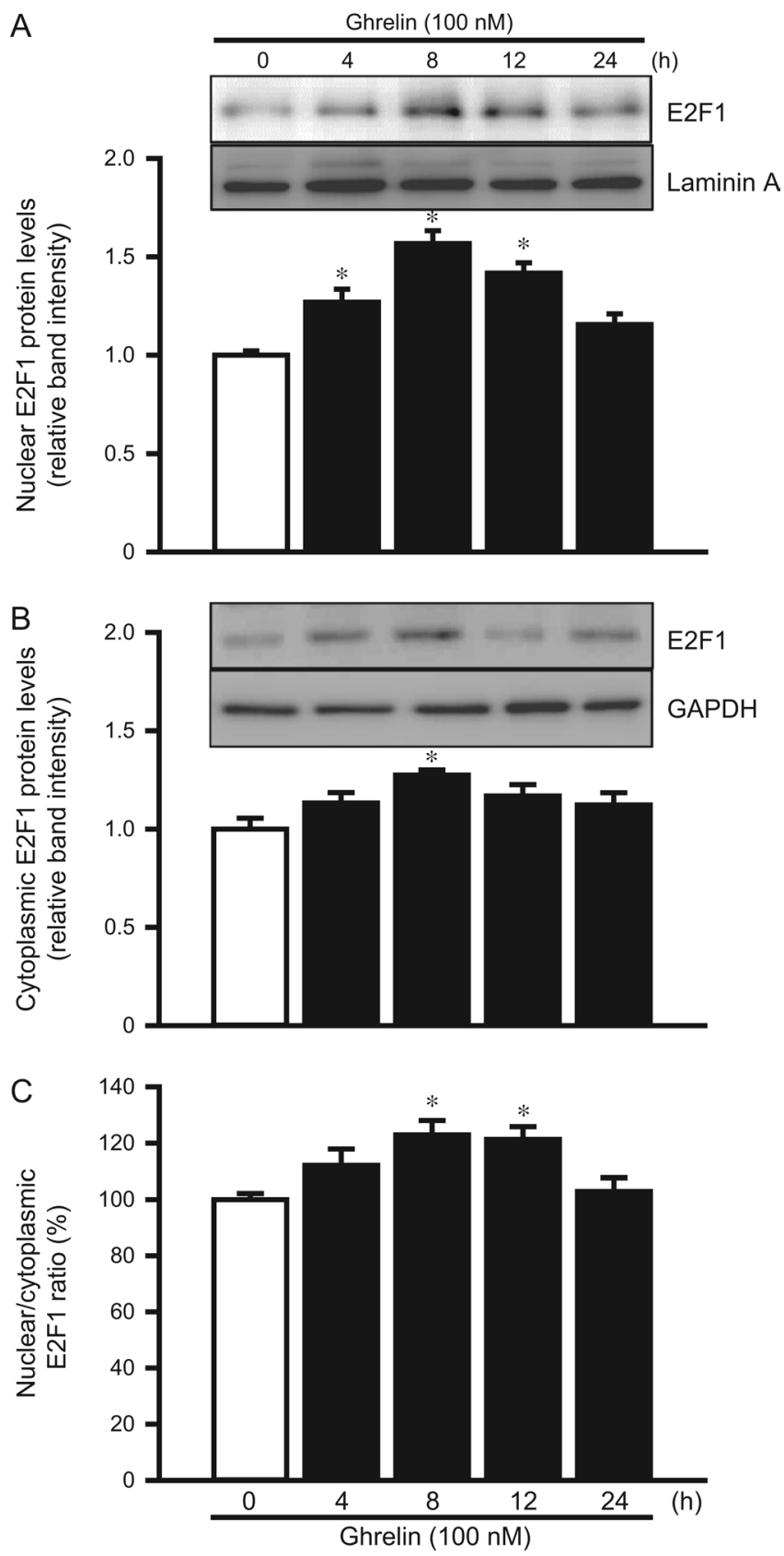

Figure 3

Ghrelin increases the nuclear expression of transcription factor E2F1. Cells were treated with ghrelin $(100 \mathrm{nM})$ for $4,8,12$ and $24 \mathrm{~h}$. Nuclear and cytoplasmic lysates were prepared and assayed by Western blotting using specific anti-E2F1, anti-laminin A and anti-GAPDH antibodies. (A) The nuclear E2F1 band intensity was normalized to the laminin $A$ band intensity. (B) The cytoplasmic E2F1 band intensity was normalized to the GAPDH band intensity. Representative Western blotting images are shown in the upper insets. The data are expressed as the mean \pm S.E.M. of three different experiments (each experiment was performed in duplicate). (C) The bar graphs represent the nuclear/cytoplasmic E2F1 ratio expressed as the percentage of control. ${ }^{*} P<0.05$ vs control. (c) 2016 Society for Endocrinology Printed in Great Britain 

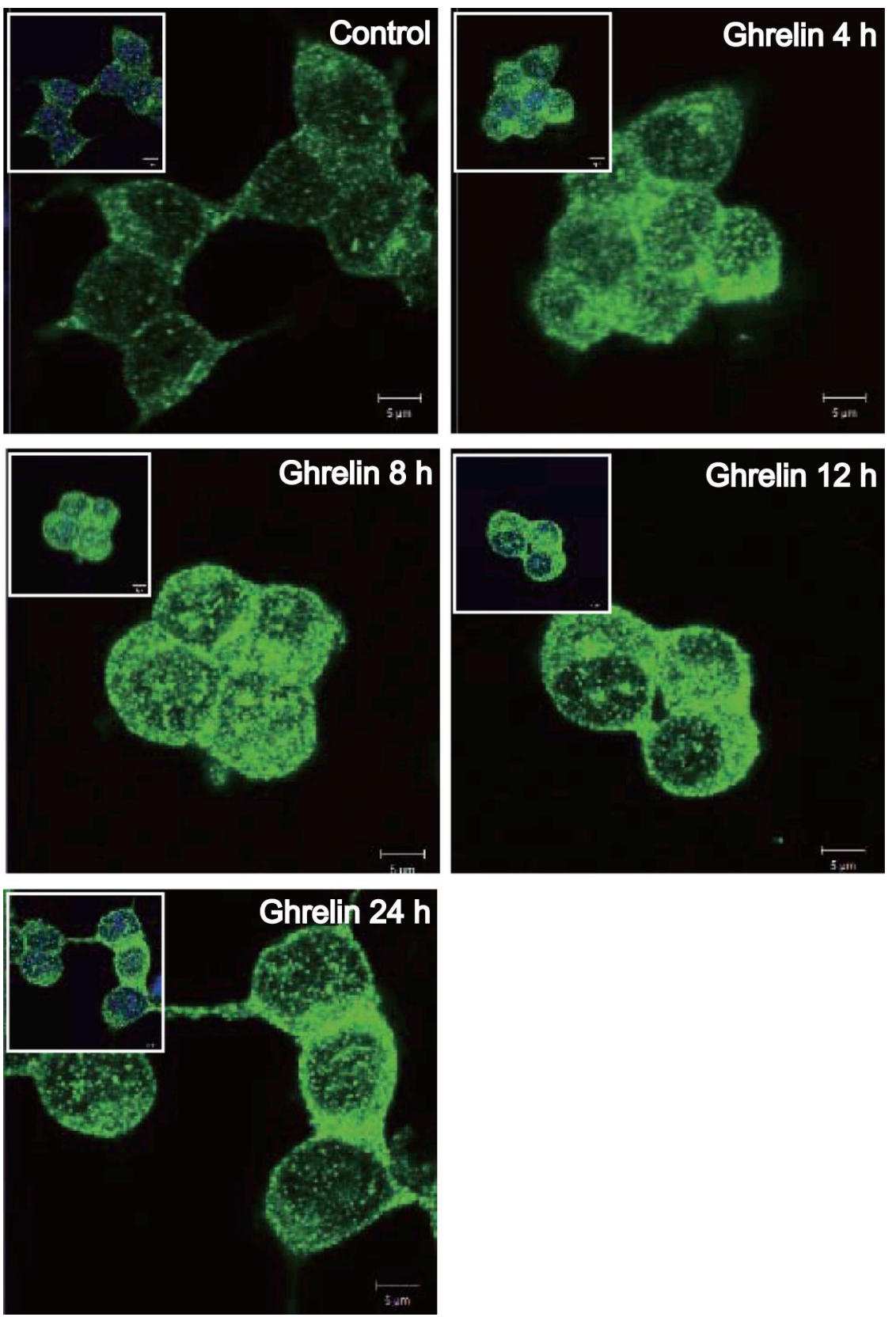

Figure 4

Confocal microscopic analysis of E2F1 expression. Cells were treated with ghrelin ( $100 \mathrm{nM})$ for 4,8 , 12 and $24 \mathrm{~h}$. Cells were incubated with primary antibody to E2F1. Cells were counterstained with DAPI, and images were captured using confocal microscopy; scale bar, $5 \mu \mathrm{m}$.

room temperature. Images were acquired by the Carl Zeiss LSM 700 Meta confocal microscope and analyzed using Carl Zeiss ZEN image software.

\section{Statistical analysis}

Data are presented as mean \pm s.e.M. of three different experiments (each experiment was performed in duplicate). Statistical analysis between groups was performed using Student's $t$-test for the comparison of two means or one-way ANOVA and the Holm-Sidak method for multiple comparisons using SigmaStat for Windows Version 3.10 (Systat Software, Inc, Point Richmond, CA, USA). $P<0.05$ was considered statistically significant.

\section{Results}

Ghrelin stimulates proliferation of adult rat hippocampal NSCs

Based on our previous results demonstrating that ghrelin increases BrdU incorporation of cultured adult

Published by Bioscientifica Ltd 
A

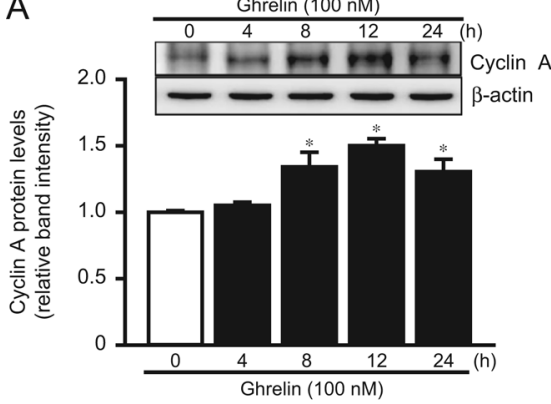

C

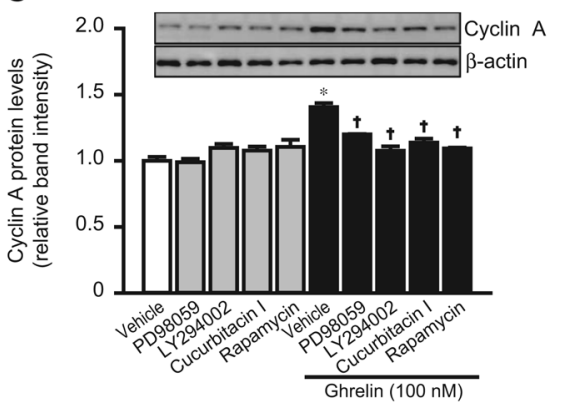

B

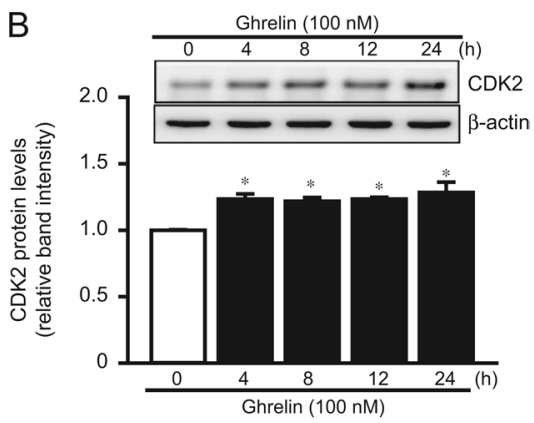

D

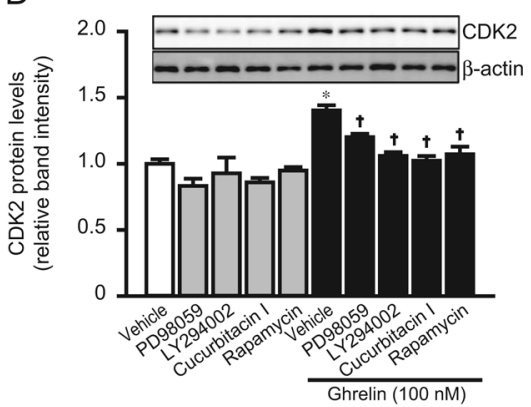

Figure 5

Ghrelin increases the expression of cyclin $A$ and CDK2. ( $A$ and $B$ ) Cells were treated with ghrelin $(100 \mathrm{nM})$ for $4,8,12$ and $24 \mathrm{~h}$. (C and D) Cells were preincubated with $20 \mu \mathrm{M}$ PD98059 for $0.5 \mathrm{~h}, 20 \mu \mathrm{M}$ LY294002 for $1 \mathrm{~h}, 200 \mathrm{nM}$ rapamycin for $1 \mathrm{~h}$ or $1 \mathrm{nM}$ cucurbitacin I for $0.5 \mathrm{~h}$ and then treated with ghrelin (100 nM) for $8 \mathrm{~h}$. Lysates were prepared and assayed by Western blotting using specific anti-cyclin $A$, anti-CDK2 and anti- $\beta$-actin antibodies. Cyclin A (A and C) and CDK2 ( $B$ and D) band intensities were normalized to the $\beta$-actin band intensity and expressed as relative band intensity. Representative Western blotting images are shown in the upper insets. The data are expressed as the mean \pm S.E.M. of three different experiments (each experiment was performed in duplicate). ${ }^{*} P<0.05$ vs control; ${ }^{+} P<0.05$ vs ghrelin-treated cells. rat hippocampal NSCs (Chung et al. 2013), CCK-8 proliferation assay was used to confirm the effect of ghrelin on cell proliferative ability. As shown in Fig. 1A, ghrelin $(100 \mathrm{nM})$ significantly increased cell proliferation in a time-dependent manner. Next, we further analyzed well-defined cell-proliferating markers, PCNA and CDC2, by Western blotting. After 24-h treatment with ghrelin $(100 \mathrm{nM})$, protein levels of PCNA and CDC2 were significantly increased by $126.3 \pm 7.9$ and $139.0 \pm 7.8 \%$, respectively ( $P<0.05$ vs vehicle-treated control), as shown in Fig. 1B. These results indicate that ghrelin increased the expression of well-known cell cycle-related genes, PCNA and CDC2, which are essential for progression through mitosis. Ghrelin also promoted the levels of mRNA for PCNA and CDC2 assessed by real-time RT-PCR (Fig. 1C).

\section{Multiple pathways are involved in ghrelin-induced cell cycle progression of adult rat hippocampal NSCs}

Our previous data indicated that pretreatment of cells with specific inhibitors of MEK/ERK1/2, PI3K/Akt, mTOR, and JAK2/STAT3 attenuated ghrelin-induced hippocampal NSCs proliferation (Chung et al. 2013). To further investigate ghrelin-induced cell proliferation, we analyzed the effect of ghrelin on cell cycle entry using FACS analysis of distribution of cells in each phase of the cell cycle. Following growth factor deprivation for $16 \mathrm{~h}$, cells were treated with vehicle or ghrelin $(100 \mathrm{nM})$ for $8 \mathrm{~h}$. In vehicle-treated cells, $84.4 \pm 0.2 \%$ of cells were in $G_{0} / G_{1}$,
$6.0 \pm 0.6 \%$ were in $S$ and $9.7 \pm 0.6 \%$ were in $\mathrm{G}_{2} / \mathrm{M}$ phase (Fig. 2A). When cells were incubated with ghrelin for $8 \mathrm{~h}$, the $G_{0} / G_{1}$ population was decreased to $80.7 \pm 0.5 \%$, the $S$ phase population was increased to $10.9 \pm 0.8 \%$ and the $\mathrm{G}_{2} / \mathrm{M}$ population was decreased to $8.4 \pm 0.7 \%$ (Fig. $2 \mathrm{~A}$ ). These results indicated that hippocampal NSCs entered the S phase after 8-h treatment with ghrelin. However, when cells were exposed to MEK1 inhibitor PD98059, MEK1/2 inhibitor U0126, PI3K inhibitor LY294002, Akt inhibitor VIII, mTOR inhibitor rapamycin or JAK2/STAT3 inhibitor cucurbitacin I, ghrelin-induced increase in $\mathrm{S}$ phase ratio was significantly attenuated (Fig. 2B).

\section{Ghrelin increases nuclear expression of transcription factor E2F1 in adult rat hippocampal NSCs}

It has been demonstrated that the transcription factor E2F1 is involved in controlling proliferation and neuronal cell numbers in the postnatal and adult brain (CooperKuhn et al. 2002). To identify changes in subcellular localization of E2F1, Western blotting was conducted to detect E2F1 in nuclear and cytoplasmic fractions. Figure 3 shows ghrelin-induced increase in E2F1 protein both in the nuclear (Fig. 3A) and cytoplasmic (Fig. 3B) fractions of cells. We also calculated the nuclear/cytoplasmic E2F1 ratio and found that ghrelin significantly increased the ratio after 8-h treatment (Fig. 3C), suggesting increased expression of E2F1 in the nucleus. These results were confirmed by immunofluorescence confocal microscopy,

Published by Bioscientifica Ltd. 
A

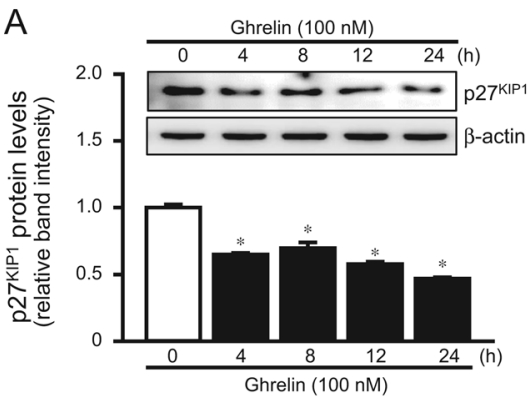

C

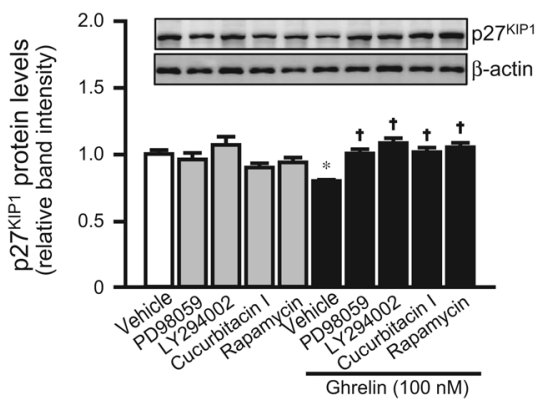

B

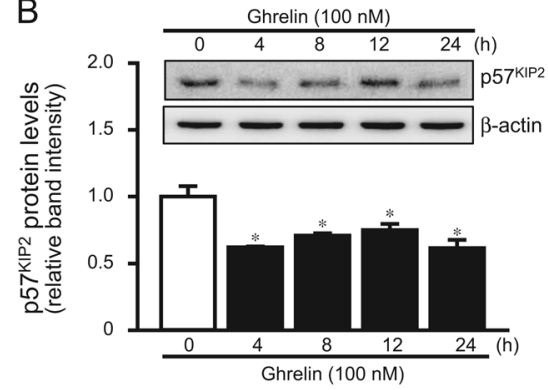

D

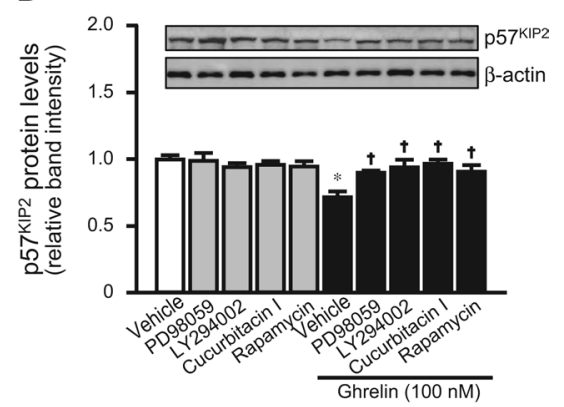

Figure 6

Ghrelin decreases the expression of p27KIP1 and p57KIP2. (A and B) Cells were treated with ghrelin $(100 \mathrm{nM})$ for $4,8,12$ and $24 \mathrm{~h}$. (C and D) Cells were preincubated with $20 \mu \mathrm{M}$ PD 98059 for $0.5 \mathrm{~h}, 20 \mu \mathrm{M}$ LY294002 for $1 \mathrm{~h}, 200 \mathrm{nM}$ rapamycin for $1 \mathrm{~h}$ or $1 \mathrm{nM}$ cucurbitacin I for $0.5 \mathrm{~h}$ and then treated with ghrelin $(100 \mathrm{nM})$ for $8 \mathrm{~h}$. Lysates were prepared and assayed by Western blotting using specific anti-p27KIP1, anti-p57KIP2 and anti- $\beta$-actin antibodies. p27KIP1 ( $A$ and $C$ ) and p57KIP2 (B and D) band intensities were normalized to the $\beta$-actin band intensity and expressed as relative band intensity. Representative Western blotting images are shown in the upper insets. The data are expressed as the mean \pm S.E.M. of three different experiments (each experiment was performed in duplicate). ${ }^{*} P<0.05$ vs control; ${ }^{+} P<0.05$ vs ghrelin-treated cells. which showed an increased staining pattern when cells were treated with ghrelin (Fig. 4).

\section{Ghrelin increases the expression of cyclin A and CDK2 in adult rat hippocampal NSCs}

To determine the mechanisms involved in ghrelin-induced proliferation of hippocampal NSCs, we examined the expression of cyclin A, which is accumulated during $\mathrm{S}$ phase (Yam et al. 2002). Regulation of expression of cyclin A is mediated by the transcription factor E2F1 (Schulze et al. 1995). As shown in Fig. 5A, ghrelin increased cyclin A protein levels in a time-dependent manner, with a significant rise after 8 -h treatment. Similar increase in protein levels of CDK2 was also observed after 4-h ghrelin treatment (Fig. 5B). We further determined which signaling pathways are involved in ghrelin-induced increase in cyclin A and CDK2 expression. We found that pretreatment of cells with PD98059, LY294002, rapamycin or cucurbitacin I significantly attenuated ghrelin-mediated enhancement of cyclin A and CDK2 protein levels (Fig. 5C and D).

\section{Ghrelin decreases the expression of p27KIP1 and p57 ${ }^{\mathrm{KIP} 2}$ in adult rat hippocampal NSCs}

We also examined the expression of two negative regulators of cell cycle, p27KIP1 and p57KIP2. We first analyzed the expression of p27KIP1, because it is likely an important CKI that induces cell cycle exit in proliferative cells (Cobrinik
2005). As shown in Fig. 6A, ghrelin treatment significantly decreased p27KIP1 protein levels by $65 \%$ at $4 \mathrm{~h}, 70 \%$ at $8 \mathrm{~h}$ and $58 \%$ at $12 \mathrm{~h}$. The protein levels of $\mathrm{p} 27 \mathrm{KIP} 1$ remained reduced even $24 \mathrm{~h}$ after ghrelin treatment, exhibiting a $47 \%$ decrease. We also examined the effect of ghrelin on the expression of p57KIP2. Ghrelin elicited a significant decrease in p57KIP2 protein levels (from 75 to $62 \%$ ) at 4,8 , 12 and $24 \mathrm{~h}$ (Fig. 6B). Next, the pathways mediating the ghrelin-induced decrease in p27KIP1 and p57KIP2 expression were examined by exposure of cells to PD98059, LY294002, rapamycin or cucurbitacin I. As shown in Fig. 6C and D, these inhibitors attenuated the decrease in p27KIP1 and p57KIP2 protein levels of cells subjected to ghrelin treatment.

\section{Discussion}

In the current study, our data indicate that ghrelininduced increase in nuclear expression of E2F1 is associated with ghrelin-mediated promotion of cell cycle progression in cultured adult rat hippocampal NSCs. The proliferative effect of ghrelin appears to be mediated by increased expression of genes that promote progression through the cell cycle, such as cyclin A and CDK2, while inhibiting expression of genes that trigger cell cycle exit, such as p27KIP1 and p57KIP2. Ghrelin-induced cell cycle progression from $G_{0} / G_{1}$ to $S$ phase was dependent on the activities of MEK/ERK1/2, PI3K/Akt/mTOR and JAK2/STAT3 signaling pathways. 
In previous paper, we found that ghrelin increased the proliferation of cultured hippocampal NSCs assessed by BrdU incorporation, suggesting mitogenic potential of ghrelin (Chung et al. 2013). In this study, the proliferative effect of ghrelin has been confirmed by CCK-8 proliferation assay and enhancement of expression of PCNA and CDC2, well-defined and commonly used cell proliferation markers (Castedo et al. 2002, Moldovan et al. 2007). PCNA, a marker for $G_{1}$ and $S$ phase, acts as a homotrimer and helps increase the processivity of leading strand synthesis during DNA replication (Moldovan et al. 2007). CDC2, also called cyclin-dependent kinase 1 , has to be active to allow cells to progress from the $G_{2}$ to the $\mathrm{M}$ phase (Castedo et al. 2002). In the current study, 24-h incubation of cells with ghrelin significantly increased the expression of PCNA and CDC2, suggesting that ghrelin augmented entry into and progression of hippocampal NSCs through the cell cycle.

To investigate the ability of ghrelin to cause hippocampal NSCs entry into the cell cycle, we performed FACS analysis of cell distribution in each phase of the cell cycle. We found that ghrelin increased the number of cells in $S$ phase with a decrease in number of cells in $G_{0} / G_{1}$ phase, indicating ghrelinmediated promotion of entry into $\mathrm{S}$ phase. Multiple signaling pathways and molecules are involved in regulation of the proliferation of neural progenitor cells. For example, a dominant negative Akt inhibits cell proliferation (Peltier et al. 2007) and the activation of ERK is important for the proliferation of neural progenitor cells (Learish et al. 2000, Zhou et al. 2004). Inhibitor of GSK-3 $\beta$, a downstream effector of Akt, promotes the proliferation of progenitor cells, while $\beta$-catenin overexpression increases the proliferation (Adachi et al. 2007). The activation of $\mathrm{mTOR} / \mathrm{p} 70^{\mathrm{s} 6 \mathrm{~K}}$ signaling has been reported to increase the proliferation of NSCs in vitro (Ryu et al. 2003). In addition, STAT3 inhibition blocked leptin-induced proliferation of adult hippocampal neural progenitor cells (Garza et al. 2008). These findings were supported by our previous report, where we showed that ghrelin increased the phosphorylation of ERK1/2, Akt, STAT3, GSK-3 $\beta$, mTOR and p70 $76 \mathrm{~K}$, and chemical inhibition of MEK/ERK1/2, PI3K/Akt, mTOR and STAT3 reversed ghrelin-induced increase in the proliferation of hippocampal NSCs (Chung et al. 2013). In agreement with these observations, we found that ghrelininduced progression into $S$ phase in hippocampal NSCs was attenuated when cells were pretreated with specific inhibitors of MEK/ERK1/2, PI3K/Akt, mTOR and
JAK2/STAT3. Taken together, our previous and current results suggest that multiple signaling pathways, such as MEK/ERK1/2, PI3K/Akt/GSK-3 $\beta$, PI3K/Akt/mTOR/p70s6K and JAK2/STAT3, are involved in ghrelin-induced cell cycle progression and proliferation of hippocampal NSCs.

In this study, we have shown that ghrelin increases the nuclear expression of E2F1, which is requisite for enabling E2F1 to reach target DNA sequences (Muller \& Helin 2000). Considering that E2F1 expression is essential in adult neurogenesis (Cooper-Kuhn et al. 2002), the increase in expression of nuclear E2F1 may contribute to ghrelin-mediated proliferation of hippocampal NSCs. The E2F1 transcription factor is known to bind exclusively to retinoblastoma $(\mathrm{Rb})$ protein in a cell cycledependent manner (Yoshikawa 2000). During the $G_{1}$ phase, the cyclin D/CDK4-6 complex phosphorylates the $\mathrm{Rb}$ protein, resulting in sequential phosphorylation by cyclin E/CDK2 and the release of free E2F1 (Abrous et al. 2005). CDK2 then combines with cyclin A to maintain the cells in $S$ phase (Beukelaers et al. 2012). Indeed, cyclin $\mathrm{A}$, a marker of $\mathrm{S}$ phase, was elevated by ghrelin and this increase was paralleled by enhanced protein levels of CDK2. Moreover, exposure of cells to PD98059, LY294002, rapamycin or cucurbitacin I resulted in significant attenuation of the stimulatory effect of ghrelin on cyclin A and CDK2 protein levels, indicating that this peptide increased the expression of cyclin $\mathrm{A}$ and CDK2 through the activation of MEK/ERK1/2, PI3K/Akt/mTOR and JAK2/STAT3 pathways. Therefore, we propose that mitotic ghrelin signaling increases cyclin A levels by stimulating nuclear expression of E2F1, leading to formation of active cyclin A/CDK2 complexes and further hyperphosphorylation of Rb. Increased activity of cyclin A/CDK2 triggers the initiation of DNA replication and thus entry into the $S$ phase of the cell cycle.

Our results suggest that, besides stimulating promitogenic cyclin A and CDK2, ghrelin also induces downregulation of cell cycle inhibitors, p27KIP1 and p57 ${ }^{\text {KIP2 }}$, to promote $S$ phase entry of hippocampal NSCs. Our data also suggest that the activation of MEK/ERK1/2, PI3K/Akt/mTOR and JAK2/STAT3 is involved in the regulation by ghrelin in p27KIP1 and p57KIP2 expression. The antimitogenic molecules $\mathrm{p} 27^{\mathrm{KIP} 1}$ and p57KIP2 negatively regulate the progression of cell cycle by binding and inhibiting complexes of cyclin E/CDK2 and cyclin $\mathrm{A} / \mathrm{CDK} 2$ and thus promote cell cycle exit in proliferative cells (Vidal \& Koff 2000, Abrous et al. 2005). Reduced levels of p27KIP1 and p57KIP2 have been implicated in the mechanism of IGF-1- or bFGF-mediated proliferative

Published by Bioscientifica Ltd. 
action in cortical precursor cells (Li \& Cicco-Bloom 2004, Mairet-Coello et al. 2009). Similar findings were also observed in IGF-1- and FGF-2-stimulated oligodendrocyte progenitor cells (Frederick \& Wood 2004). In the current study, we have shown that ghrelin downregulates p27KIP1 and $\mathrm{p} 57_{\mathrm{KIP} 2}$, helping to trigger entry into $\mathrm{S}$ phase of hippocampal NSCs. It is likely that ghrelin mitigates inhibitory influence on cyclin/CDK activity by the reduced expression of p27 KIP1 and p57KIP2.

Combining the current results and previous studies, ghrelin seems to be a plausible candidate that improves hippocampus-dependent cognitive function. The supporting evidences are as follows. (1) Adult neurogenesis in the DG has been proposed to mediate hippocampus-dependent learning and memory (Zhao et al. 2008). (2) We and others have previously reported that ghrelin-deleted mice showed impairments in memory performance, which was rescued by exogenous peripheral administration of ghrelin (Diano et al. 2006, Li et al. 2013). (3) In calorie-restricted animals, where plasma ghrelin levels are elevated (Lutter et al. 2008), survival of newborn cells in the DG has been increased in wild-type mice (Lee et al. 2002), but not in ghrelin-knockout mice (Kim et al. 2015) and enhanced memory performance in hippocampus-dependent behavioral test was observed (Fontan-Lozano et al. 2007, Adams et al. 2008).

In conclusion, our observations indicate that ghrelin has a mitogenic effect in cultured hippocampal NSCs. Ghrelin-induced mitogenic regulation may be mediated via enhanced progression from $G_{1}$ to $S$ phase due to enhanced nuclear expression of E2F1 and opposite regulation of positive and negative cell cycle regulators. Therefore, ghrelin may be a possible beneficial approach for the impairments in learning and memory performance observed in various neurodegenerative diseases.

\section{Declaration of interest}

The authors declare that there is no conflict of interest that could be perceived as prejudicing the impartiality of the research reported.

\section{Funding}

This research was supported by the National Research Foundation of Korea (NRF) grant funded by the Korea government (MSIP) (No. 2011-0030072 to S P and No. 2014R1A1A2058316 to H C)

\section{Author contribution statement}

Hyunju Chung: carried out the laboratory experiments, collected the data and wrote the manuscript. Seungjoon Park: designed the study, analyzed and interpreted the data and wrote the manuscript.

\section{References}

Abizaid A, Liu ZW, Andrews ZB, Shanabrough M, Borok E, Elsworth JD, Roth RH, Sleeman MW, Picciotto MR, Tschop MH, et al. 2006 Ghrelin modulates the activity and synaptic input organization of midbrain dopamine neurons while promoting appetite. Journal of Clinical Investigation 116 3229-3239. (doi:10.1172/JCI29867)

Abrous DN, Koehl M \& Le MM 2005 Adult neurogenesis: from precursors to network and physiology. Physiological Reviews 85 523-569. (doi:10.1152/physrev.00055.2003)

Adachi K, Mirzadeh Z, Sakaguchi M, Yamashita T, Nikolcheva T, Gotoh Y, Peltz G, Gong L, Kawase T, Alvarez-Buylla A, et al. 2007 Beta-catenin signaling promotes proliferation of progenitor cells in the adult mouse subventricular zone. Stem Cells 25 2827-2836. (doi:10.1634/ stemcells.2007-0177)

Adams MM, Shi L, Linville MC, Forbes ME, Long AB, Bennett C, Newton IG, Carter CS, Sonntag WE, Riddle DR, et al. 2008 Caloric restriction and age affect synaptic proteins in hippocampal CA3 and spatial learning ability. Experimental Neurology 211 141-149. (doi:10.1016/j.expneurol.2008.01.016)

Beukelaers P, Vandenbosch R, Caron N, Nguyen L, Moonen G \& Malgrange B 2012 Cycling or not cycling: cell cycle regulatory molecules and adult neurogenesis. Cellular and Molecular Life Sciences 69 1493-1503. (doi:10.1007/s00018-011-0880-6)

Brewer GJ, Torricelli JR, Evege EK \& Price PJ 1993 Optimized survival of hippocampal neurons in B27-supplemented Neurobasal, a new serum-free medium combination. Journal of Neuroscience Research $\mathbf{3 5}$ 567-576. (doi:10.1002/jnr.490350513)

Carey RG, Li B \& Cicco-Bloom E 2002 Pituitary adenylate cyclase activating polypeptide anti-mitogenic signaling in cerebral cortical progenitors is regulated by p57Kip2-dependent CDK2 activity. Journal of Neuroscience 22 1583-1591.

Carlini VP, Varas MM, Cragnolini AB, Schioth HB, Scimonelli TN \& de Barioglio SR 2004 Differential role of the hippocampus, amygdala, and dorsal raphe nucleus in regulating feeding, memory, and anxietylike behavioral responses to ghrelin. Biochemical and Biophysical Research Communications 313 635-641. (doi:10.1016/ j.bbrc.2003.11.150)

Castedo M, Perfettini JL, Roumier T \& Kroemer G 2002 Cyclin-dependent kinase-1: linking apoptosis to cell cycle and mitotic catastrophe. Cell Death \& Differentiation 9 1287-1293. (doi:10.1038/sj.cdd.4401130)

Chung H, Kim E, Lee DH, Seo S, Ju S, Lee D, Kim H \& Park S 2007 Ghrelin inhibits apoptosis in hypothalamic neuronal cells during oxygen-glucose deprivation. Endocrinology 148 148-159. (doi:10.1210/en.2006-0991)

Chung H, Seo S, Moon M \& Park S 2008 Phosphatidylinositol-3-kinase/ Akt/glycogen synthase kinase-3 beta and ERK1/2 pathways mediate protective effects of acylated and unacylated ghrelin against oxygen-glucose deprivation-induced apoptosis in primary rat cortical neuronal cells. Journal of Endocrinology 198 511-521. (doi:10.1677/ JOE-08-0160)

Chung H, Li E, Kim Y, Kim S \& Park S 2013 Multiple signaling pathways mediate ghrelin-induced proliferation of hippocampal neural stem cells. Journal of Endocrinology 218 49-59. (doi:10.1530/ JOE-13-0045)

Cobrinik D 2005 Pocket proteins and cell cycle control. Oncogene 24 2796-2809. (doi:10.1038/sj.onc.1208619)

Cooper-Kuhn CM, Vroemen M, Brown J, Ye H, Thompson MA, Winkler J \& Kuhn HG 2002 Impaired adult neurogenesis in mice lacking the transcription factor E2F1. Molecular and Cellular Neuroscience 21 312-323. (doi:10.1006/mcne.2002.1176)

Date Y, Kojima M, Hosoda H, Sawaguchi A, Mondal MS, Suganuma T, Matsukura S, Kangawa K \& Nakazato M 2000 Ghrelin, a novel growth hormone-relasing acylated peptide, is synthesized in a distinct endocrine cell type in the gastrointestinal tracts of rats and humans. Endocrinology 141 4255-4261. (doi:10.1210/en.141.11.4255) 
Diano S, Farr SA, Benoit SC, McNay EC, da Silva I, Horvath B, Gaskin FS, Nonaka N, Jaeger LB, Banks WA, et al. 2006 Ghrelin controls hippocampal spine synapse density and memory performance. Nature Neuroscience 9 381-388. (doi:10.1038/nn1656)

Fontan-Lozano A, Saez-Cassanelli JL, Inda MC, de los SantosArteaga M, Sierra-Dominguez SA, Lopez-Lluch G, gado-Garcia JM \& Carrion AM 2007 Caloric restriction increases learning consolidation and facilitates synaptic plasticity through mechanisms dependent on NR2B subunits of the NMDA receptor. Journal of Neuroscience 27 10185-10195. (doi:10.1523/ JNEUROSCI.2757-07.2007)

Frederick TJ \& Wood TL 2004 IGF-I and FGF-2 coordinately enhance cyclin D1 and cyclin E-cdk2 association and activity to promote G1 progression in oligodendrocyte progenitor cells. Molecular and Cellular Neuroscience 25 480-492. (doi:10.1016/j.mcn.2003.11.015)

Garza JC, Guo M, Zhang W \& Lu XY 2008 Leptin increases adult hippocampal neurogenesis in vivo and in vitro. Journal of Biological Chemistry 283 18238-18247. (doi:10.1074/jbc. M800053200)

Ghigo E, Broglio F, Arvat E, Maccario M, Papotti M \& Muccioli G 2005 Ghrelin: more than a natural GH secretagogue and/or an orexigenic factor. Clinical Endocrinology 62 1-17. (doi:10.1111/ j.1365-2265.2004.02160.x)

Hwang S, Moon M, Kim S, Hwang L, Ahn KJ \& Park S 2009 Neuroprotective effect of ghrelin is associated with decreased expression of prostate apoptosis response-4. Endocrine Journal 56 609-617. (doi:10.1507/endocrj.K09E-072)

Jiang H, Betancourt L \& Smith RG 2006 Ghrelin amplifies dopamine signaling by cross talk involving formation of growth hormone secretagogue receptor/dopamine receptor subtype 1 heterodimers. Molecular Endocrinology 20 1772-1785. (doi:10.1210/me.2005-0084)

Jiang H, Li LJ, Wang J \& Xie JX 2008 Ghrelin antagonizes MPTP-induced neurotoxicity to the dopaminergic neurons in mouse substantia nigra. Experimental Neurology 212 532-537. (doi:10.1016/ j.expneurol.2008.05.006)

Kim Y, Kim S, Kim C, Sato T, Kojima M \& Park S 2015 Ghrelin is required for dietary restriction-induced enhancement of hippocampal neurogenesis: lessons from ghrelin knockout mice. Endocrine Journal 62 269-275. (doi:10.1507/endocrj.EJ14-0436)

Kojima M \& Kangawa K 2005 Ghrelin: structure and function. Physiological Reviews 85 495-522. (doi:10.1152/ physrev.00012.2004)

Kojima M, Hosoda H, Date Y, Nakazato M, Matsuo H \& Kangawa K 1999 Ghrelin is a growth hormone-relesasing acylated peptide from stomach. Nature 402 656-660. (doi:10.1038/45230)

Learish RD, Bruss MD \& Haak-Frendscho M 2000 Inhibition of mitogen-activated protein kinase kinase blocks proliferation of neural progenitor cells. Developmental Brain Research 122 97-109. (doi:10.1016/S0165-3806(00)00064-X)

Lee J, Seroogy KB \& Mattson MP 2002 Dietary restriction enhances neurotrophin expression and neurogenesis in the hippocampus of adult mice. Journal of Neurochemistry 80 539-547. (doi:10.1046/ j.0022-3042.2001.00747.x)

Lee J, Lim E, Kim Y, Li E \& Park S $2010 a$ Ghrelin attenuates kainic acid-induced neuronal cell death in the mouse hippocampus Journal of Endocrinology 205 263-270. (doi:10.1677/joe-10-0040)

Lee JY, Chung H, Yoo YS, Oh YJ, Oh TH, Park S \& Yune TY $2010 b$ Inhibition of apoptotic cell death by ghrelin improves functional recovery after spinal cord injury. Endocrinology 151 3815-3826. (doi:10.1210/en.2009-1416)

Lee JH, Patel K, Tae HJ, Lustig A, Kim JW, Mattson MP \& Taub DD 2014 Ghrelin augments murine T-cell proliferation by activation of the phosphatidylinositol-3-kinase, extracellular signal-regulated kinase and protein kinase C signaling pathways. FEBS Letters $\mathbf{5 8 8}$ 4708-4719. (doi:10.1016/j.febslet.2014.10.044)
Li B \& Cicco-Bloom E 2004 Basic fibroblast growth factor exhibits dual and rapid regulation of cyclin D1 and p27 to stimulate proliferation of rat cerebral cortical precursors. Developmental Neuroscience 26 197-207. (doi:10.1159/000082137)

Li E, Chung H, Kim Y, Kim DH, Ryu JH, Sato T, Kojima M \& Park S 2013 Ghrelin directly stimulates adult hippocampal neurogenesis: implications for learning and memory. Endocrine Journal 60 781-789. (doi:10.1507/endocrj.ej13-0008)

Lutter M, Sakata I, Osborne-Lawrence S, Rovinsky SA, Anderson JG, Jung S, Birnbaum S, Yanagisawa M, Elmquist JK, Nestler EJ, et al. 2008 The orexigenic hormone ghrelin defends against depressive symptoms of chronic stress. Nature Neuroscience 11 752-753. (doi:10.1038/nn.2139)

Mairet-Coello G, Tury A \& Cicco-Bloom E 2009 Insulin-like growth factor-1 promotes $\mathrm{G}(1) / \mathrm{S}$ cell cycle progression through bidirectional regulation of cyclins and cyclin-dependent kinase inhibitors via the phosphatidylinositol 3-kinase/Akt pathway in developing rat cerebral cortex. Journal of Neuroscience 29 775-788. (doi:10.1523/ JNEUROSCI.1700-08.2009)

Miao Y, Xia Q, Hou Z, Zheng Y, Pan H \& Zhu S 2007 Ghrelin protects cortical neuron against focal ischemia/reperfusion in rats. Biochemical and Biophysical Research Communications 359 795-800. (doi:10.1016/ j.bbrc.2007.05.192)

Ming GL \& Song H 2005 Adult neurogenesis in the mammalian central nervous system. Annual Review of Neuroscience 28 223-250. (doi:10.1146/annurev.neuro.28.051804.101459)

Moldovan GL, Pfander B \& Jentsch S 2007 PCNA, the maestro of the replication fork. Cell 129 665-679. (doi:10.1016/ j.cell.2007.05.003)

Moon M, Kim HG, Hwang L, Seo JH, Kim S, Hwang S, Kim S, Lee D, Chung H, Oh MS, et al. 2009a Neuroprotective effect of ghrelin in the 1-methyl-4-phenyl-1,2,3,6-tetrahydropyridine mouse model of Parkinson's disease by blocking microglial activation. Neurotoxicity Research 15 332-347. (doi:10.1007/s12640-0099037-x)

Moon M, Kim S, Hwang L \& Park S 2009b Ghrelin regulates hippocampal neurogenesis in adult mice. Endocrine Journal 56 525-531. (doi:10.1507/endocrj.k09e-089)

Muller H \& Helin K 2000 The E2F transcription factors: key regulators of cell proliferation. Biochimica et Biophysica Acta 1470 M1-M12. (doi:10.1016/s0304-419x(99)00030-x)

Naleid AM, Grace MK, Cummings DE \& Levine AS 2005 Ghrelin induces feeding in the mesolimbic reward pathway between the ventral tegmental area and the nucleus accumbens. Peptides 26 2274-2279. (doi:10.1016/j.peptides.2005.04.025)

Patricio P, Mateus-Pinheiro A, Sousa N \& Pinto L 2013 Re-cycling paradigms: cell cycle regulation in adult hippocampal neurogenesis and implications for depression. Molecular Neurobiology 48 84-96. (doi:10.1007/s12035-013-8422-x)

Peltier J, O'Neill A \& Schaffer DV 2007 PI3K/Akt and CREB regulate adult neural hippocampal progenitor proliferation and differentiation. Developmental Neurobiology 67 1348-1361. (doi:10.1002/dneu.20506)

Ryu JK, Choi HB, Hatori K, Heisel RL, Pelech SL, McLarnon JG \& Kim SU 2003 Adenosine triphosphate induces proliferation of human neural stem cells: role of calcium and p70 ribosomal protein S6 kinase. Journal of Neuroscience Research 72 352-362. (doi:10.1002/jnr.10507)

Schulze A, Zerfass K, Spitkovsky D, Middendorp S, Berges J, Helin K, Jansen-Durr P \& Henglein B 1995 Cell cycle regulation of the cyclin A gene promoter is mediated by a variant E2F site. PNAS 92 11264-11268. (doi:10.1073/pnas.92.24.11264)

Van der Lely AJ, Tschop M, Heiman ML \& Ghigo E 2004 Biological, physiological, pathophysiological, and pharmacological aspects of ghrelin. Endocrine Reviews 25 426-457. (doi:10.1210/er.2002-0029) http://joe.endocrinology-journals.org

DOI: $10.1530 / J O E-16-0126$
(C) 2016 Society for Endocrinology Printed in Great Britain 
Vidal A \& Koff A 2000 Cell-cycle inhibitors: three families united by a common cause. Gene 247 1-15. (doi:10.1016/S0378-1119(00)00092-5)

Waseem T, Duxbury M, Ashley SW \& Robinson MK 2014 Ghrelin promotes intestinal epithelial cell proliferation through PI3K/Akt pathway and EGFR trans-activation both converging to ERK 1/2 phosphorylation. Peptides 52 113-121. (doi:10.1016/ j.peptides.2013.11.021)

Yam CH, Fung TK \& Poon RY 2002 Cyclin A in cell cycle control and cancer. Cellular and Molecular Life Sciences 59 1317-1326. (doi:10.1007/s00018-002-8510-y)
Yoshikawa K 2000 Cell cycle regulators in neural stem cells and postmitotic neurons. Neuroscience Research 37 1-14. (doi:10.1016/ S0168-0102(00)00101-2)

Zhao C, Deng W \& Gage FH 2008 Mechanisms and functional implications of adult neurogenesis. Cell 132 645-660. (doi:10.1016/j. cell.2008.01.033)

Zhou L, Del Villar K, Dong Z \& Miller CA 2004 Neurogenesis response to hypoxia-induced cell death: map kinase signal transduction mechanisms. Brain Research 1021 8-19. (doi:10.1016/j. brainres.2004.05.115)

Received in final form 14 June 2016

Accepted 20 June 2016

Accepted Preprint published online 20 June 2016
Published by Bioscientifica Ltd 